\title{
The Human Capital Dimension To Foreign Direct Investment: Training, Adverse Selection and Firm Location*
}

\author{
Theo S. Eicher \\ University of Washington \\ and \\ Pantelis Kalaitzidakis \\ University of Cyprus \\ First version May 1996 \\ This version: May 1997
}

\begin{abstract}
While the theoretical literature on Foreign Direct Investment (FDI) focuses largely on movements in capital and firm specific technology, recent empirical evidence emphasizes primarily the local human capital necessary to absorb FDI technology. We examine how human capital affects FDI and add a new dimension to the trade and FDI literature: informational asymmetries. Multinationals (MNCs) must train labor to work with firm specific technology, but employers possess incomplete information about workers' abilities. We integrate an adverse selection model into a general equilibrium framework, and introduce Informational Gains From Trade.

Examining the incentives for firm location, we can explain why FDI is more likely to occur among countries that are similar in terms of human capital and technology, and why there is little investment from developing countries in advanced economies. Informational asymmetries coupled with human capital differences give rise to empirical observed multiple wage equilibria, where MNCs pay the highest wage in advanced countries, but higher wages than domestic firms in developing countries. The dynamic analysis highlights the absence of scale effects in the model, driven by the fact that the costs of training workers with fixed human capital will eventually outweigh any benefits from productivity increases generated by research expenditures.
\end{abstract}

* We thank Erik Bond, Bjarne S. Jensen, Kar Yiu Wong, and the discussant Jan I. Haaland for helpful comments. 


\section{INTRODUCTION}

The development literature emphasizes technology transfers as a central aspect of take-off and convergence of growth rates. Arguably the most important channel of technology transfer is foreign direct investment (FDI). While theoretical models of FDI and firm location focus largely on technology and physical capital, recent empirical evidence underscores that the success of technology transfer via FDI depends crucially on the size of the developing country's human capital stock (Borensztein, DeGregorio, and Lee [1995]). In addition, Hummels and Stern [1994] document that the lion share of FDI occurs among nations with similar technology and human capital levels.

This paper examines the role of multinational corporations (MNCs) in facilitating international technological diffusion, and the role of human capital in determining firm location. In focusing on human capital, we introduce a new dimension to trade and FDI: informational asymmetries. We combine an efficiency wage approach to labor markets with a model of trade and FDI by embedding an adverse selection model into a two sector general equilibrium framework that extends to the open economy. This allows us to analyze the human capital dimension to trade and FDI: the choice of firm location when investment in firm specific training is affected by adverse selection problems.

Labor market information asymmetries have not yet been analyzed in the international trade and location literature This is surprising, since a key aspect of firm location is ownership advantage, e.g., a firm specific production process, blueprint or technology (Dunning [1977] and [1981]). When workers are heterogeneous in their abilities to learn about this ownership advantage and MNCs are unable to judge individual skills perfectly, MNCs cannot make full use of their ownership advantage. Any location model is thus incomplete without the specification of a distinct information set that determines how employers form expectations about worker productivity.

Our model features only one factor, heterogeneous labor. The level of human capital is important to firm location because domestic workers must learn about firm specific technologies, and firms must provide these skills through training. Investment in our model is thus investment in people and skills. We assume with Kalaitzidakis [1996] that the training efficiency depends on 
worker quality, which contains both observable and unobservable components. Since MNCs cannot ascertain workers' training efficiency with certainty ex ante, firms' hiring and location decisions are subject to adverse selection problems. The model consists of two sectors, agriculture and manufacturing. The agricultural sector establishes a reservation wage through self-employment, while the manufacturing sector pays an efficiency wage to counter the adverse selection problem. Agents differ in their productive abilities within countries, and in both their abilities and their observable human capital across countries.

The model yields a number of insights that are new to trade and foreign direct investment literature, but reminiscent of the implications of efficiency wage models. Adverse selection generates a pattern of static comparative advantage that is akin to both the Heckscher Ohlin and the Ricardian model. As in the Ricardian model, countries with more sophisticated technologies feature higher wages and export the technology intensive good. Reminiscent of the Heckscher Ohlin model, human capital abundant countries adopt more sophisticated technologies and possess a comparative advantage in the learning intensive good. Unlike in the Heckscher Ohlin model, a human capital abundant country that shares identical technologies with all other countries, features a higher manufacturing wage, because the expected quality of its applicant pool is higher. We also find that a country that shares the same levels of human capital and technology with all other countries, but possesses a larger labor endowment, has a comparative advantage in agriculture, because the size of the population increases the adverse selection problem firms face.

In contrast to the Heckscher Ohlin model, trade is associated with falling (rising) wages in the developed (developing) country. The wage convergence signals a novel effect introduced by the addition of adverse selection to trade: informational efficiency gains from trade. These gains arise because both countries relocate production to the sector where workers have a comparative advantage in terms of production and informational efficiency. The country with the comparative advantage in training expands production of the training intensive good, pays lower efficiency wages, but also enjoys a higher quality applicant pool. That is, trade diminishes the effect of the informational asymmetries in the developed country's manufacturing sector. Informational gains also accelerate the adjustment and increase the output of the agricultural good in the LDC. 
The analysis of location reveals that the incentive to open subsidiaries in foreign countries diminishes with the technological and human capital differences between countries, as discussed by Borensztein, DeGregorio and Lee [1995]. The larger the difference in human capital levels across countries, the greater the effect of the informational asymmetry on the training efficiency for the MNC. Also, the more pronounced the technology gap between countries, the higher the training costs for MNCs. If a firm opens a production plant in a foreign country, we find that informational asymmetries naturally give rise to the type of multiple wage equilibria observed by Feenstra and Hanson [1995], and Aitken, Harrison and Lipsey [1995]. That is, MNCs pay higher wages than domestic firms in equilibrium, because MNCs use higher levels of technology than domestic firms and therefore seek to attract higher quality workers to minimize training costs. Interestingly enough, the MNC pays workers in the foreign country less than in the home country, since information and training cost are higher in the developing country, where the cohort is of observationally lower quality. This is what we term the human capital dimension to foreign direct investment. Finally we examine the dynamics of the model and find that our equilibrium is locally saddle point stable. However, sustained growth comes to a halt, despite endogenous technological change, because the training cost per worker eventually outpaces productivity increases.

Labor market information asymmetries have not been extensively analyzed in the international trade literature, which commonly assumed perfect information in labor markets. Dixit [1989] models adverse selection in an open economy, but informational asymmetries exist only between entrepreneurs and policy makers. Moral hazard has been introduced into trade models by Copeland [1989], and Bulow and Summer [1986], who examine commercial policy; and by Brecher [1992], and Brecher and Choudhri [1994], who examine the welfare effects of commercial policy given unemployment. Informational asymmetries have been introduced into various other areas of the open economy. Markusen [1995] provides an exhaustive survey of the analysis of moral hazard problems associated with licensing agreements that multinationals face. Ethier [1986] examines incomplete contracts, Dixit [1989] examines commercial policy in a model where the probability of success in a risky production sector is private information; and in a model where the migration decision is a function of the small open economy's stochastic terms of trade 
(Dixit [1994]).

The adverse selection problems that firms face when hiring heterogeneous workers under imperfect information, was first explicitly modeled by Weiss [1980]. Weiss showed that such market imperfections require employers to identify the mass of workers that accrue the minimum cost per efficiency unit of labor. Nalebuff and Stiglitz [1982] subsequently present a model where increases in wages increase the expected ability of the applicant pool because lower quality applicants see their probability of being hired diminish. We will utilize the insights of these adverse selection models to model how firms select applicants and efficiency wages below. The empirical evidence on the informational asymmetries in labor markets is scarce. There is little evidence for moral hazard, but compelling evidence for adverse selection problems, as documented by Foster and Rosenzweig [1993]. Their study concludes that higher productivity workers participate less in time wage markets when the return to piece rate (self-employment) work increases. Foster and Rosenzweig also show that there is considerable ignorance among employers about the individual difference in workers' abilities in developing countries.

\section{A GENERAL EQUILIBRIUM ADVERSE SELECTION MODEL}

\subsection{Agriculture}

We make two assumptions that pay tribute to the traditional notion of agricultural sectors. First, the sector is one of self-employment. Workers opt to work in agriculture only when they do not find employment in manufacturing, or when the value of their marginal product in agriculture exceeds the wage they would receive in manufacturing. Second, we choose a linear production function not only to simplify matters, but also to reflect the traditional notion that the marginal product equals the average product in the agricultural sectors. The total output of the agricultural good, $\mathrm{X}$, is given by

$$
X=\sum_{i=0}^{L^{X}} \mathrm{G}[\theta(\mathrm{i}), \mathrm{H}], \quad \mathrm{i} \in[0, \mathrm{~L}], \mathrm{G}_{\mathrm{H}}>0, \mathrm{G}_{\theta}>0,
$$

where subscripts indicate partial derivatives. $\mathrm{L}$ are the total units of labor in the economy, which divide themselves into agricultural and manufacturing employment, $\mathrm{L}^{\mathrm{X}}$ and $\mathrm{L}^{\mathrm{Y}}$, respectively. Productivity, G[ $\theta(\mathrm{i}), \mathrm{H}]$, depends on the quality of the individual worker, which consists of two 
components: observable human capital, $H$, and unobservable ability, $\theta$. H represents the average level of human capital (e.g., years of schooling) that is observable in a country. Once we

introduce trade we will assume that $\mathrm{H}$ varies exogenously across countries and that $\mathrm{H}_{\mathrm{j}}, \mathrm{j}=0,1,2, \ldots$, can be ordered across countries so that $\mathrm{H}_{0}$ represents the country with the lowest level of average general human capital. We suppress country indicator superscript unless needed.

Since each self-employed worker knows her ability, $\theta$, there exist no informational asymmetries in the agricultural sector. Hence, the return to labor in agriculture is known with certainty to each individual. We label the value of the marginal product in agriculture the reservation wage, $\omega^{\mathrm{i}}$, of worker $\mathrm{i}$ with human capital $\mathrm{H}$ at price $\pi$, or

$$
\omega^{\mathrm{i}}=\pi \mathrm{G}[\theta(\mathrm{i}), \mathrm{H}],
$$

where $\pi$ represents the relative price of the agricultural good. Given that higher quality workers have higher productivity, the following derivatives are straightforward: $\partial \omega^{\mathrm{i}} / \partial \mathrm{H}>0, \partial \omega^{\mathrm{i}} / \partial \pi>0$, and $\partial \omega^{\mathrm{i}} / \partial \theta>0$.

\subsection{Manufacturing}

For simplicity, we assume that each country possesses just one firm and one representative technology, $A$. The firm's production function for manufacturing output, $\mathrm{Y}$, is given by

$$
\mathrm{Y}=\mathrm{F}\left[\mathrm{T}[\mathrm{A}] \mathrm{L}^{\mathrm{Y}}\right] \text { with } \mathrm{F}^{\prime}[.]>0, \mathrm{~F}^{\prime \prime}[.]<0, \mathrm{~T}^{\prime}[.]>0 \text {, and } \mathrm{T}^{\prime \prime}[.]>0 \text {. }
$$

The productivity of labor, T[.], depends on firm specific technology $A$. To be able to work with $A$, labor must acquire firm specific skills. Since skills are firm specific, the employer must pay the training cost (Becker [1975]). We assume with Kalaitzidakis [1996] that firms incur training costs that are a function of worker quality. Specifically, we express the cost of training worker $i$ as

$$
\overline{\mathrm{C}}^{\mathrm{i}}[q[\theta(\mathrm{i}), \mathrm{H}], \mathrm{A}]=\mathrm{T}[\mathrm{A}] \mathrm{C}[\mathrm{q}[\theta(\mathrm{i}), \mathrm{H}]], \quad \text { with } \mathrm{C}^{\prime}[.]<0 \text { and } \mathrm{C}^{\prime \prime}[.]>0,
$$

where, for simplicity, training costs depend linearly on the amount of training required for each specific technology, T[A]. The training efficiency, q[.], of worker i (i.e., how easily a worker can learn new skills) is determined by the worker's quality, $\theta(i)$ and $H$. Using equation (2) we can write training efficiency as $\mathrm{q}\left[\omega^{\mathrm{i}}, \pi, \mathrm{H}\right]$, with $\mathrm{q}_{\omega}>0$ and $\mathrm{q}_{\pi}<0$.

The manufacturing sector is, however, marred by informational asymmetries. Firms hire workers whose training efficiency depends on their quality, which is not known with certainty to 
the employer. Manufacturers may observe general human capital, H, across countries (i.e., from UNESCO educational attainment statistics), but not the exact ability of each applicant, $\theta$ (i.e., how fast an individual worker learns about the firm specific technology). These informational asymmetries create an adverse selection problem and firms realize that the quality of the applicant pool deteriorates at any given level of observed human capital as the manufacturing wage declines.

While firms cannot observe the quality of worker $i$ ex ante, they are capable of generating beliefs about the applicant pool's expected quality on the basis of workers' reservation wages. Since the reservation wage is increasing in $\theta$, firms may use the manufacturing wage, w, to influence the expected quality of their applicant pool. Hence, following Weiss [1990], firms base their hiring decisions on the expected quality, Q,

$$
\mathrm{Q}[\mathrm{w}, \mathrm{H}, \pi]=\frac{\int_{0}^{\mathrm{w}} \mathrm{q}\left[\mathrm{w}^{\mathrm{i}}, \pi, \mathrm{H}\right] \mathrm{D}\left[\mathrm{w}^{\mathrm{i}}\right] \mathrm{dw}^{\mathrm{i}}}{\int_{0}^{\mathrm{w}} \mathrm{D}\left[\mathrm{w}^{\mathrm{i}}\right] \mathrm{dw}}
$$

where $D\left[\omega^{i}\right]$ gives the mass of workers with reservation wage $\omega^{\mathrm{i}}$. Equation (5) states that at a given relative price $\pi$, firms can expect an applicant with observable human capital $H$ to possess quality $\mathrm{Q}$, at a given wage offer, w. From $\mathrm{q}_{\omega}>0$ and $\mathrm{q}_{\pi}<0$, it follows that $\mathrm{Q}_{\mathrm{w}}>0$ and $\mathrm{Q}_{\pi}<0$. In addition, we assume that, at a given wage, the expected quality increases in the level of observable human capital, or $\mathrm{Q}_{\mathrm{H}}>0$. We also assume that $\mathrm{Q}_{\pi \pi}<0, \mathrm{Q}_{\mathrm{ww}}<0$, and $\mathrm{Q}_{\mathrm{w} \pi}=0$. We can now rewrite the firm's training cost per worker as

$$
\overline{\mathrm{C}}=\mathrm{T}[\mathrm{A}] \mathrm{C}[\mathrm{Q}[\mathrm{w}, \mathrm{H}, \pi]] \text {. }
$$

The manufacturing firm's problem then consists of maximizing profits, $\rho$, over employment and wages

$$
\max _{\mathrm{w}, \mathrm{L}^{\mathrm{Y}}} \rho=\mathrm{F}\left[\mathrm{T}[\mathrm{A}] \mathrm{L}^{\mathrm{Y}}\right]-\left(\mathrm{w}+\mathrm{T}[\mathrm{A}] \mathrm{C}[\mathrm{Q}[\mathrm{w}, \mathrm{H}, \pi]) \mathrm{L}^{\mathrm{Y}} .\right.
$$

The first order conditions can then be derived as

$$
\mathrm{T}[\mathrm{A}] \mathrm{C}^{\prime}[\mathrm{Q}[\mathrm{w}, \mathrm{H}, \pi]] \mathrm{Q}_{\mathrm{w}}[\mathrm{w}, \mathrm{H}, \pi]=-1,
$$




$$
\mathrm{F}^{\prime}\left[\mathrm{T}[\mathrm{A}] \mathrm{L}^{\mathrm{Y}}\right]=\frac{\mathrm{w}}{\mathrm{T}[\mathrm{A}]}+\mathrm{C}[\mathrm{Q}[\mathrm{w}, \mathrm{H}, \pi]]
$$

Equation (8) solves for the optimal number of workers employed at any given wage. It simply states that the marginal product must equal the marginal cost to firms, where the cost depends on both the wage and the expected training costs. It will be convenient to define the productivity adjusted cost as the Average Efficiency Cost (AEC) of the firm with technology $A$ as

$$
\begin{gathered}
\mathrm{AEC} \equiv \frac{\mathrm{w}+\mathrm{T}[\mathrm{A}] \mathrm{C}[\mathrm{Q}[\mathrm{w}, \mathrm{H}, \pi]]}{\mathrm{T}[\mathrm{A}]} \\
\text { with }\left.\frac{\partial \mathrm{AEC}}{\partial \mathrm{w}}\right|_{\mathrm{w}^{*}}=0 \text {, and } \frac{\partial^{2} \mathrm{AEC}}{\partial \mathrm{w}^{2}}=\mathrm{C}^{\prime \prime}[\mathrm{Q}] \mathrm{Q}_{\mathrm{w}}^{2}+\mathrm{C}^{\prime}[\mathrm{Q}] \mathrm{Q}_{\mathrm{ww}}>0 .
\end{gathered}
$$

That is, the efficiency wage minimizes the AEC of firms; and the AEC is convex in the wage. The minimization of the AEC or, equivalently, the profit maximizing wage condition, equation (7), determines the efficiency wage, $\mathrm{w}^{*}=\mathrm{w}^{*}[\mathrm{~A}, \mathrm{H}, \pi]$, as a function of the exogenous parameters: technology, observable human capital, and the (partial equilibrium) relative price. Equation (7) replicates the typical efficiency wage condition that, at equilibrium, a unitary decrease in the wage cost must generate an equal increase in the training cost. Also, equations (7) and (8) reproduce the usual efficiency wage result that, as long as the labor constraint is not binding at $\mathrm{w}^{*}$, the wage determines the amount of labor employed, instead of vice versa. That is, firms choose productivity and training efficiency of their workers optimally and independently of the amount of labor supplied at any given wage. ${ }^{1}$ Equations (7) and (9) yield

$$
\begin{aligned}
\frac{\partial \mathrm{w}^{*}}{\partial \pi} & =-\frac{\mathrm{C}^{\prime \prime}[\mathrm{Q}] \mathrm{Q}_{\pi} \mathrm{Q}_{\mathrm{w}}}{\partial^{2} \mathrm{AEC} / \partial \mathrm{w}^{2}}>0, \text { and } \frac{\partial \mathrm{AEC}^{*}}{\partial \pi}=\mathrm{C}^{\prime}[\mathrm{Q}] \mathrm{Q}_{\pi}>0, \\
\frac{\partial \mathrm{w}^{*}}{\partial \mathrm{H}} & =-\frac{\mathrm{C}^{\prime \prime}[\mathrm{Q}] \mathrm{Q}_{\mathrm{H}} \mathrm{Q}_{\mathrm{w}}+\mathrm{C}^{\prime}[\mathrm{Q}] \mathrm{Q}_{\mathrm{wH}}}{\partial^{2} \mathrm{AEC} / \partial \mathrm{w}^{2}}>0, \text { and } \frac{\partial \mathrm{AEC}^{*}}{\partial \mathrm{H}}=\mathrm{C}^{\prime}[\mathrm{Q}] \mathrm{Q}_{\mathrm{H}}<0, \\
\frac{\partial \mathrm{w}^{*}}{\partial \mathrm{A}} & =\frac{\mathrm{T}^{\prime}[\mathrm{A}]}{\mathrm{T}[\mathrm{A}]^{2}\left(\partial^{2} \mathrm{AEC} / \partial \mathrm{w}^{2}\right)}>0, \text { and } \frac{\partial \mathrm{AEC}^{*}}{\partial \mathrm{A}}=-\frac{\mathrm{w} \mathrm{T}^{\prime}[\mathrm{A}]}{\mathrm{T}[\mathrm{A}]^{2}}<0 .
\end{aligned}
$$

It is instructive to report both the changes in wages and AECs because the two need not move in

\footnotetext{
${ }^{1}$ For the purposes of this paper we assume that the manufacturing sector's labor supply exceeds labor demand at any given wage. The analysis of excess labor demand in adverse selection models is standard and can be reviewed in Weiss [1990].
} 
the same direction. While wages are an important part of AEC, so are the training costs, which depend on the quality of the applicant pool. If wages rise due to an increase in the relative price, then the AEC increases because firms see the quality of their applicant pool deteriorate as the value of the marginal product in agriculture rises. If, however, wages increase because firms face higher levels of observable human capital or technology, the AEC declines. In response to an increase in technology, firms raise the efficiency wage to offset increased training costs with higher quality workers. Since higher quality workers possess a comparative advantage in training and learning about more sophisticated technologies, the AEC declines.

An increase in human capital, at any given level of technology, implies two effects akin to a change in the relative price and technology. While higher human capital workers also have higher reservation wages, firms see the average quality of the applicant pool increase. Since high human capital workers also possess a comparative advantage in learning about new technologies, the net effect of an increase in the level of human capital is upward pressure on the efficiency wage, but lower AEC.

In competitive models, when wages are directly tied to the marginal product of workers, or in models of perfect information, wages and output (employment) are usually inversely related. This need not be so in the case when firms pay efficiency wages that are influenced by worker quality or technological skill requirements. Equations (3) and (8) yield straight forward relations between manufacturing output and the three key variables:

$$
\begin{aligned}
\frac{\partial \mathrm{Y}^{*}}{\partial \pi} & =\mathrm{T}[\mathrm{A}] \mathrm{F}^{\prime}[.] \frac{\partial \mathrm{L}^{\mathrm{Y}^{*}}}{\partial \pi}=\frac{\mathrm{F}^{\prime}[.]}{\mathrm{F}^{\prime \prime}[.]} \frac{\partial \mathrm{AEC}^{*}}{\partial \pi}<0, \\
\frac{\partial \mathrm{Y}^{*}}{\partial \mathrm{H}} & =\mathrm{T}[\mathrm{A}] \mathrm{F}^{\prime}[.] \frac{\partial \mathrm{L}^{\mathrm{Y}^{*}}}{\partial \mathrm{H}}=\frac{\mathrm{F}^{\prime}[.]}{\mathrm{F}^{\prime \prime}[.]} \frac{\partial \mathrm{AEC}^{*}}{\partial \mathrm{H}}>0, \\
\frac{\partial \mathrm{Y}^{*}}{\partial \mathrm{A}} & =\mathrm{F}^{\prime}[.]\left(\mathrm{T}^{\prime}[\mathrm{A}] \mathrm{L}^{\mathrm{Y}}+\mathrm{T}[\mathrm{A}] \frac{\partial \mathrm{L}^{*}}{\partial \mathrm{A}}\right)=\frac{\mathrm{F}^{\prime}[.]}{\mathrm{F}^{\prime \prime}[\mathrm{A}]} \frac{\partial \mathrm{AEC}}{\partial \mathrm{A}}>0 .
\end{aligned}
$$

Manufacturing output falls as the relative price increases, since the increase in the value of the marginal product in agriculture lowers the quality of the applicant pool in manufacturing. Firms are forced to increase the efficiency wage, just to hold training costs constant. The increase in the average and total cost decreases profits which induces a contraction in output through 
employment. The partial equilibrium effects of increases in human capital and technology are positive on output in the manufacturing sector. Output in the manufacturing sector increases in both cases because workers are more productive. However, in the case of increased technology firms also face higher training costs. As firms are faced with increased training costs, they raise the efficiency wage to attract more able workers with a comparative advantage in training.

\subsection{Demand}

Most efficiency wage models, with the exception of Phelps [1994], abstract from an explicit demand side and are thus susceptible to nagging doubts that general equilibrium considerations might overturn the partial equilibrium results. To establish a meaningful notion of comparative advantage, we turn to the demand side to construct a two sector general equilibrium adverse selection model. Our introduction of two qualitatively different sectors not only represents the informational asymmetries across sectors and countries, but also allows for a complete and standard demand side that permits for a meaningful discussion of relative prices and trade.

Agents maximize utility, $\mathrm{U}$, which is a function of their consumption of the agricultural and manufacturing good, $\mathrm{X}$ and $\mathrm{Y}$,

$$
\mathrm{U}=\mathrm{a} \ln \mathrm{X}+\ln \mathrm{Y}
$$

subject to their individual budget constraints that are determined by their income derived from their ownership in firms, plus their efficiency wage income or their income from self-employment in agriculture. Utility maximization yields the standard relation between relative demand and relative price

$$
\mathrm{a} \frac{\mathrm{Y}}{\mathrm{X}}=\pi \text {. }
$$

\section{STATIC COMPARATIVE ADVANTAGE}

The condition that supply must equal demand in the closed economy, or

$$
\mathrm{a} \frac{\mathrm{F}\left[\mathrm{T}[\mathrm{A}] \mathrm{L}^{\mathrm{Y}}\right]}{\sum_{i=0}^{\mathrm{L}-\mathrm{L}^{\mathrm{Y}}} \mathrm{G}[\boldsymbol{\theta}(\mathrm{i}), \mathrm{H}]}
$$

renders the equilibrium relative price in the closed economy, $\pi^{*}=\pi^{*}[\mathrm{~A}, \mathrm{H}, \mathrm{L}, \mathrm{a}]$, a function of technology, observable human capital, the population size, preferences, and the ability distribution 
of a country. We refrain from assuming any specific distribution for $\theta$ and assert that these distributions are identical across countries. The comparative statics that involve the size of the labor force, L, are then based on the assumption of mean and spread preserving increases in the population and its abilities. ${ }^{2}$ Differentiation of equation (14) yields the following insights into the static comparative advantage:

$$
\begin{aligned}
& \frac{\partial \pi^{*}}{\partial \mathrm{L}}=-\frac{\mathrm{a} \frac{\mathrm{Y}}{\mathrm{X}^{2}} \frac{\partial \mathrm{X}^{*}}{\partial \mathrm{L}}}{1-\mathrm{a} \frac{\partial(\mathrm{Y} / \mathrm{X})}{\partial \pi}}<0, \\
& \frac{\partial \pi^{*}}{\partial \mathrm{H}}=\frac{\frac{\mathrm{a}}{\mathrm{X}^{2}}\left(\mathrm{X} \frac{\partial \mathrm{Y}^{*}}{\partial \mathrm{H}}-\mathrm{Y} \frac{\partial \mathrm{X}^{*}}{\partial \mathrm{H}}\right)}{1-\mathrm{a} \frac{\partial(\mathrm{Y} / \mathrm{X})}{\partial \pi}}>0, \\
& \frac{\partial \pi^{*}}{\partial \mathrm{A}}=\frac{\frac{\mathrm{a}}{\mathrm{X}^{2}}\left(\mathrm{X} \frac{\partial \mathrm{Y}^{*}}{\partial \mathrm{A}}-\mathrm{Y} \frac{\partial \mathrm{X}^{*}}{\partial \mathrm{A}}\right)}{1-\mathrm{a} \frac{\partial(\mathrm{Y} / \mathrm{X})}{\partial \pi}}>0, \\
& \frac{\partial \pi^{*}}{\partial \mathrm{a}}=\frac{\mathrm{Y} / \mathrm{X}}{1-\mathrm{a} \frac{\partial(\mathrm{Y} / \mathrm{X})}{\partial \pi}>0 .}
\end{aligned}
$$

The denominator is positive in all cases, as it is simply one minus the slope of the relative supply curve. An increase in $\pi$ has two separate effects. First, it decreases employment in manufacturing, as explained in equation (11a); second, it depresses the expected quality of the applicant pool, which elevates the AEC. Despite firms' attempts to raise the efficiency wage to diminish the deterioration in the quality of their applicant pool, quality declines. ${ }^{3}$ Output of $\mathrm{X}(\mathrm{Y})$ rises (falls) unambiguously.

Once the sign of the denominator is established, the responses of the relative price due to

\footnotetext{
${ }^{2}$ It is easily proven that mean preserving increases in the spread of distributions increase the AEC.

$3 \frac{\mathrm{dQ}}{\mathrm{d} \pi}=\mathrm{Q}_{\pi}\left(\frac{\mathrm{C}^{\prime}[\mathrm{Q}] \mathrm{Q}_{\mathrm{ww}}}{\mathrm{C}^{\prime \prime}[\mathrm{Q}] \mathrm{Q}_{\mathrm{w}}^{2}+\mathrm{C}^{\prime}[\mathrm{Q}] \mathrm{Q}_{\mathrm{ww}}}\right)$
} 
changes in population and preferences are simple to sign. Ceteris paribus, a mean and spread preserving increase in the population depresses the relative price of the agricultural good, but both sectors expand. Initially, all new workers would start in the agricultural sector, since the labor demand in manufacturing is solely determined by the efficiency wage condition. As the value of the marginal product in agriculture declines, firms can offer lower efficiency wages and attract the same expected quality applicant pool, which encourages manufacturing employment. However, since the efficiency wage is independent of the amount of labor in the economy, or even the amount of labor supplied at any given wage offered, the agricultural sector's increase in supply dominates and the relative price falls. Hence countries with larger populations, even if they have the same level of observable human capital, exhibit lower efficiency wages and have a comparative advantage in the agricultural good, simply due to the adverse selection problem that firms face.

Greater preferences for the agricultural good raise the value of the marginal product in agriculture, which increases the training cost as the quality of workers forthcoming at any given wage declines. Output of the agricultural good rises while that of the manufacturing good declines. Increases in the level of technology and human capital increase the relative supply of the manufacturing good. In both cases the relative supply effect dominates the downward price pressure from the demand side. A higher level of technology implies a lower productivity adjusted wage. This allows firms to employ higher quality workers by increasing the efficiency wage. The quality of workers in manufacturing increases and with it the level of output, while output of the agricultural good decreases unambiguously. A higher level of human capital has the same effect. At any given wage, firms can attract higher quality workers, which lowers their AEC. Firms will raise the efficiency wage to compensate for the increased training efficiency and hire more workers. While fewer workers remain in the agricultural sector, and while the manufacturing sector is hiring workers of higher quality than before, the increase in $\mathrm{H}$ also increases the agricultural productivity, $\mathrm{G}[\theta(\mathrm{i}), \mathrm{H}]$, which is taken to be dominated by the increase in output in the manufacturing sector. ${ }^{4}$ In summary, a country with lower levels of technology or

\footnotetext{
${ }^{4}$ To avoid perverse price responses we only consider the case we find intuitively most compelling, i.e., we restrict ourselves to distributions of G[.] that render the elasticity of output with respect to $\mathrm{H}$ smaller in agriculture than in
} 
human capital, and with greater labor endowment or preferences for the agricultural good will have a comparative advantage in the agricultural sector.

Having determined the effect of a change in the equilibrium price on the key variables, we can now derive the general equilibrium effects of higher technology and human capital on the efficiency wage.

$$
\begin{aligned}
& \frac{d w^{*}}{d A}=\frac{\partial w^{*}}{\partial \pi} \frac{\partial \pi^{*}}{\partial A}+\frac{\partial w^{*}}{\partial A}>0 \\
& \frac{d w^{*}}{d H}=\frac{\partial w^{*}}{\partial \pi} \frac{\partial \pi^{*}}{\partial H}+\frac{\partial w^{*}}{\partial H}>0
\end{aligned}
$$

Increases in human capital and technology cause positive direct and indirect effects on the wage. Higher levels of technology or observable human capital increase the relative price of the agricultural good (eqs. 15b and 15c), which exerts upward pressure on the efficiency wage, because it decreases the quality of workers forthcoming at the current efficiency wage. In addition, higher levels of technology or observable human capital also induce firms to raise wages directly to lower their AEC, since higher quality workers have a comparative advantage in learning about new technologies (eqs. 10b and 10c).

In summary, the introduction of informational asymmetries, adverse selection and efficiency wages generates a pattern of static comparative advantage that is akin to both the Heckscher Ohlin and the Ricardian model. As in the Ricardian model, the country with the more sophisticated technology features the higher wages and exports the good that is technology intensive. Reminiscent of the Heckscher Ohlin model, the observable human capital abundant country possesses a comparative advantage in the learning intensive good. Hence this country adopts more technology and exports the technology intensive good. Unlike the Heckscher Ohlin model, however, if two countries share the same technology, the human capital abundant country features the higher return to human capital in autarchy. Firms in the human capital abundant country can afford to pay higher wages because workers possess training efficiency. In fact, the higher quality of the applicant pool renders the AEC comparatively lower in the human capital

manufacturing when the amount of labor and the relative quality in agriculture decline. 
abundant country. In general we find that

$$
\begin{aligned}
& \frac{\mathrm{dAEC}^{*}}{\mathrm{dA}}=\frac{\partial \mathrm{AEC}^{*}}{\partial \pi} \frac{\partial \pi^{*}}{\partial \mathrm{A}}+\frac{\partial \mathrm{AEC}^{*}}{\partial \mathrm{A}}=\mathrm{C}^{\prime}[\mathrm{Q}] \mathrm{Q}_{\pi} \frac{\partial \pi^{*}}{\partial \mathrm{A}}-\frac{\mathrm{w} \mathrm{T}^{\prime}[\mathrm{A}]}{\mathrm{T}[\mathrm{A}]^{2}} \stackrel{>}{=} 0, \\
& \frac{\mathrm{dAEC}^{*}}{\mathrm{dH}}=\frac{\partial \mathrm{AEC}^{*}}{\partial \pi} \frac{\partial \pi^{*}}{\partial \mathrm{H}}+\frac{\partial \mathrm{AEC}^{*}}{\partial \mathrm{H}}=\mathrm{C}^{\prime}[\mathrm{Q}] \mathrm{Q}_{\pi} \frac{\partial \pi^{*}}{\partial \mathrm{H}}+\mathrm{C}^{\prime}[\mathrm{Q}] \mathrm{Q}_{\mathrm{H}} \stackrel{>}{\stackrel{<}{<}} 0 .
\end{aligned}
$$

The AEC is convex in both the level of human capital and in the level of technology. ${ }^{5}$ The AEC is convex in the level of technology since eventually the decline in the productivity adjusted wage is dominated by the increase in the training cost. We already know that if we assume identical prices and technologies, the minimum AEC will be lower in the country with the higher human capital (eq. 10b). If prices are allowed to vary, however, eventually the increase in relative price of the agricultural good is sufficiently strong to decrease the quality of the applicant pool to such an extent that the cost of attracting higher ability workers outweighs the benefit of paying lower productivity adjusted wage.

Similarly, at any given efficiency wage the quality of the applicant pool rises when the level of human capital increases. The associated decline in the training cost lowers the AEC only until the decrease in the quality of the applicant pool, due to an increase in the relative price of the agricultural good, dominates. The change in the AEC raises the question if it would be profitable for a firm to train workers or adopt new technologies forever, since AEC eventually rises.

\section{EXOGENOUS TECHNOLOGICAL CHANGE AND ENDOGENOUS ADOPTION}

To examine the robustness of the comparative static results, we introduce dynamic elements into the model, namely technological change and endogenous adoption. In learning about the process of technology adoption and how this affects profits, we provide a foundation for the examination of trade and firm location. To build intuition, we begin by examining the equilibrium for the case where technological change evolves exogenously at rate $\gamma$, or $\mathrm{dA} / \mathrm{dt}=\gamma \mathrm{A}$. In section 6 we then characterize the dynamics when technological change is endogenous.

This section's assumption of one "world technology", $A_{t}$, that evolves exogenously is identical to the assumption in Mankiw, Romer and Weil [1992], which produced good fits in

${ }^{5}$ Convexity of the AEC curve with respect to A requires a strong effect of technology on the relative price, $\partial^{2} \pi / \partial \mathrm{A}^{2}>0$, and a declining productivity adjusted wage in technology, $\mathrm{d}(\mathrm{w} / \mathrm{T}[\mathrm{A}]) / \mathrm{dA}<0$. 
cross country growth regressions. From equations (3), (6) and (17) we can now find the effects of a change in technology on equilibrium profits and output:

$$
\begin{aligned}
& \frac{d \rho_{t}}{d A_{t}}=-L_{t}^{Y} \frac{d A E C_{t}^{*}}{d A_{t}}, \\
& \frac{d Y_{t}}{d A_{t}}=\frac{F^{\prime}[.]}{F^{\prime \prime}[.]} \frac{\mathrm{dAEC}_{t}^{*}}{d_{t}} .
\end{aligned}
$$

The dynamic analysis of production and adoption implies a minimum AEC locus that depends only on the exogenous parameters of the model, $(\overline{\mathrm{AEC}} *[\mathrm{~A} ; \mathrm{H}, \mathrm{a}, \mathrm{L}]$ in Figure 1). Equations (18) and (19) imply that firms adopt new technologies only up to the point where the $\overline{\mathrm{AEC}} *$ is at its minimum. If firms continued to adopt technology beyond the minimum $\overline{\mathrm{AEC}} *$, output and profits would contract. Hence, the dynamic analysis assures us that we can rule out all cases where firms would ever be on the upward sloping part of the $\overline{\mathrm{AEC}} *$.

The fact that firms cease to adopt new technologies beyond some critical level implies zero long run growth, despite the fact that ever new technologies are available to firms, free of charge. The general equilibrium adverse selection model is thus entirely void of scale effects, in terms of growth rates and levels. Recent empirical research has emphasized the apparent absence of scale effects in the data. ${ }^{6}$ In this model, the complete absence of scale effects is a function of the constancy of human capital, which implies rising training costs as long as technological adoption continues. The crucial importance of the complementarily of human capital and technology has previously been stressed by Young [1993] and Eicher [1996].

Figure 1 also allows for an examination of how different levels of human capital affect the rate of technological adoption. The dotted line shows the $\overline{\mathrm{AEC}} *$ for a country with a higher level of human capital than the country with the solid line. From equations (17b) and (16b) we know that such a country would possess a lower $\overline{\mathrm{AEC}}^{*}$ and a higher efficiency wage, which implies that countries with a relatively higher human capital, and with a comparative advantage in learning

\footnotetext{
6 Strong empirical evidence for non scale growth has been presented by Easterly et. al. [1993] in a large cross country data set, and in careful analysis by Jones [1995] for OECD countries. For a general theoretical discussion of non scale models see Eicher and Turnovsky [1996].
} 
about new technologies, adopt a relatively more sophisticated technology.

We can also combine the dynamic effect of technological change with our previous insights into how changes in price alters the min $\overline{\mathrm{AEC}} *$, or the maximum level of technology adopted by firms. If the price of the manufacturing good rises (for example, because a country with a comparative advantage in the manufacturing good opens to international trade), the $\overline{\mathrm{AEC}} *$ shifts down at any given level of technology and wages decrease (eq. 10a). However, we can show that

$$
\frac{\mathrm{d}^{2} \mathrm{AEC}}{\mathrm{dAd} \pi}=\mathrm{C}^{\prime \prime}[\mathrm{Q}] \mathrm{Q}_{\pi} \frac{\mathrm{dQ}}{\mathrm{dA}}+\mathrm{C}^{\prime}[\mathrm{Q}] \mathrm{Q}_{\pi \pi} \frac{\partial \pi^{*}}{\partial \mathrm{A}}>0
$$

which implies that as revenues (temporarily) outweigh training costs, firms deem further adoption of technology profitable. Hence, trade induces new, but temporary, incentives for technological adoption and growth in the advanced country. Conversely, the LDC would find even fewer incentives to adopt new technologies, because revenues fall in the manufacturing sector.

\section{TRADE AND FIRM LOCATION}

\subsection{Informational Efficiency Gains from Trade}

Since long run growth is zero and firms never adopt technologies that raise their AEC, even if the use of that technology was free, we return to the static analysis of trade and firm location, without loss of generality. We simplify matters further by restricting ourselves to the small open economy analysis below. To derive crucial intuition about the trade pattern, we assume initially that countries differ in human capital, but share identical technologies. Then we examine the implications for firm location when countries differ also in their levels of technology.

Let us commence by designating the country with the higher (lower) level of human capital, $\mathrm{H}_{1}\left(\mathrm{H}_{0}\right)$, as DC (LDC). Both countries have identical preferences and population sizes. With identical technologies, the DC has an absolute advantage in both sectors due to its higher level of observable human capital. As shown above, the DC possesses a comparative advantage in the manufacturing sector (eq. 15b), since workers with higher human capital possess greater training efficiency and generate lower AECs. This implies a greater relative supply of the manufacturing good and relatively higher efficiency wages, compared to the LDC (eq. 16b). 
Opening to trade decreases (increases) the relative price of the agricultural good in the DC (LDC), which induces a downward (upward) shift of the AEC curve (eq. 10a). The decline (rise) in the relative price also depresses (raises) the efficiency wage and shifts the average cost curve left (right) (eq. 10a). The relation between AEC and the efficiency wage is the essence of the model and it is graphed in Figure 2. Figure 2 reports the AECs under autarchy (solid lines) and free trade (dotted lines). The two country analysis reveals cross country wage convergence due to international trade. In the Heckscher Ohlin model, trade also induces wage convergence but through low (high) and rising (falling) manufacturing wages in the human capital abundant (short) country. Empirically we observe, however, relatively higher average wages in skill abundant countries. ${ }^{7}$

While the effects of opening to trade might be standard, its mechanism of adjustment is novel and interesting. Wage convergence signals a new effect generated by the introduction of adverse selection to the theory of international trade: the movements in the efficiency adjusted cost curves reflect what we term informational efficiency gains from trade. The informational efficiency gains from trade arise because both countries relocate production to the sector where workers have a comparative advantage in terms of production and informational efficiency. The country with the comparative advantage in training expands production of the training intensive good, pays lower efficiency wages, but also enjoys a higher quality applicant pool. That is, trade diminishes the effect of the informational asymmetries in the DC's manufacturing sector.

Under autarchy, the high relative supply of the agricultural good in the DC depresses the quality of the applicant pool at any given wage, and a large fraction of high quality workers are drawn into agriculture. This effect increases the informational cost to the DC's manufacturing firm and contributes to the high efficiency wage offer. Opening to trade creates profit incentives to expand output in manufacturing and lowers the reservation wage in the agricultural sector. The latter effect increases the quality of the applicant pool for manufacturing firms. This lowers the DC's manufacturers' AECs and lowers the efficiency wage, because the quality of the applicant pool increases. Hence the term informational efficiency gain from trade.

${ }^{7}$ For empirical evidence on cross country wage convergence see, among many others, Eicher [1995] and Davis [1992]. 
While the empirical evidence for efficiency wages is scant and often inconclusive, there exists support for the wage/efficiency adjustment mechanism outlined above. Tests of efficiency wage theories have produced no conclusive support for shirking or monitoring models, but Foster and Rosenzweig [1993] find the evidence for the existence of efficiency wages due to adverse selection. Their study reports that variations in reservation wages positively influence efficiency wages paid. Krueger [1988] previously established that higher wages increase the quality of the applicant pool.

Informational gains also accelerate the adjustment and increase the output of the agricultural good in the LDC. As long as the LDC is incompletely specialized, its manufacturing firm must pay a higher efficiency wage under free trade. Because of its excessively low autarchy price, firms in the LDC were able to attract excessively high quality workers to the manufacturing sector at relatively low efficiency wages. As the value of the marginal product in agriculture rises under trade, the quality of the applicant pool in manufacturing declines, which provides an added incentive to contract the manufacturing sector. Both countries experience a Pareto improvement because of the standard static consumption, production and the additional informational efficiency gains from trade.

\subsection{Firm Location}

Thus far we have embedded an adverse selection model into a general equilibrium framework and added the insights of the informational efficiency gains from trade and wage convergence due to efficiency gains. The analysis of section 5.1 does not lend itself to the analysis of firm location since firms share identical technologies. As mentioned in the introduction, a prerequisite to the analysis of firm location is that there exists (i) a factor that is internal to the firm (in this case firm-specific training), and (ii) a factor that provides a unique ownership advantage to the firm (in this case technology).

To examine the decision to locate, we must introduce countries that differ not only in observable human capital, but also in technology. This is a natural assumption in light of our discussion of endogenous adoption, where we have shown that the countries with higher levels of human capital also adopt higher levels of technology in the long run. Let us then redefine DC (LDC) as the country which has relatively higher (lower) levels of technology, $\mathrm{A}_{1}\left(\mathrm{~A}_{0}\right)$, in addition 
to relatively higher (lower) levels of observable human capital, $\mathrm{H}_{1}\left(\mathrm{H}_{0}\right)$. Both countries continue to have identical preferences and population sizes.

The introduction of technological differences in addition to human capital differences, intensifies the DC's comparative advantage in the manufacturing sector. The DC now features an even greater relative supply of the manufacturing good, and its manufacturing sector pays an even greater efficiency wage, compared to the LDC (equations (15b), (15c), and (16)). Figure 3 shows that opening to trade, the associated decline in the relative price of the agricultural good in the DC leads again to familiar shifts in AECs and wages, as discussed in Figure 2. In the LDC, the increase in the value of the marginal product in agriculture increases the reservation wage and makes it even more difficult to attract workers for manufacturing. The LDC's manufacturing sector is hurt not only by the price effect but also by the informational aspect that the quality of the applicant pool declines, as discussed above. Again we observe wage convergence across countries.

Having introduced technological differences between the countries, we can draw an additional average efficiency curve (bold dotted) that represents the AEC of a firm which produces the manufacturing good with technology $\mathrm{A}_{1}$, and human capital $\mathrm{H}_{0}$. We know from equations $(10 \mathrm{~b})$ and $(10 \mathrm{c})$ that

$$
\begin{gathered}
\operatorname{AEC}^{*}\left[\mathrm{H}_{0}, \mathrm{~A}_{0}, \pi\right]>\operatorname{AEC}^{*}\left[\mathrm{H}_{0}, \mathrm{~A}_{1}, \pi\right]>\operatorname{AEC}^{*}\left[\mathrm{H}_{1}, \mathrm{~A}_{1}, \pi\right], \\
\mathrm{w}^{*}\left[\mathrm{H}_{0}, \mathrm{~A}_{0}, \pi\right]<\mathrm{w}^{*}\left[\mathrm{H}_{0}, \mathrm{~A}_{1}, \pi\right]<\mathrm{w}^{*}\left[\mathrm{H}_{1}, \mathrm{~A}_{1}, \pi\right] .
\end{gathered}
$$

That is, if the DC's manufacturing firm were to locate part of its production to the LDC, the relocation would require that firm to train LDC workers to work with DC technology. Because the LDC cohort is of observationally lower quality, the DC's AEC (wage) in the LDC is higher (lower) than in the DC (eqs. (16) and (10)). This is the human capital dimension to direct foreign investment. Also, since the DC's plant in the LDC trains workers to produce with higher technology, $\mathrm{A}_{1}$, than the LDC firm uses, $\mathrm{A}_{0}$, the DC's subsidiary in the LDC pays a higher wage, attracts higher quality workers and provides more training than the LDC's manufacturing firm. Hence firm location generates a multiple-wage equilibrium, as seen in Figure 3.

Notice, however, that, with two firms, a strategic interaction enters into the wage setting mechanism, because firms offering low wages improve the quality of distribution of workers 
applying to higher wage firms. This problem is well known and has previously been addressed by Weiss [1990]. To proxy the labor market interaction between domestic and foreign firms, it is useful to assume that expected quality is also a negative function of the wage offered by a competitor firm, $\mathrm{w}^{\mathrm{c}}$, or $\mathrm{Q}\left[\mathrm{w}, \mathrm{H}, \pi, \mathrm{w}^{\mathrm{c}}\right]$ with $\partial \mathrm{Q}[.] / \partial \mathrm{w}^{\mathrm{c}}<0$. This implies that if a competitor enters with a higher wage, $\mathrm{w}^{\mathrm{c}}>\mathrm{w}$, the competitor firm skims the cream of the crop workers from the distribution and lowers the expected quality of workers attracted by the firm offering wage w.

Let's analyse the wage setting mechanism for the case where the MNC enters with a higher technology than the domestic firm. Formally, we require a sequence of actions where first, each firm announces a wage offer and the number of job openings. We assume that workers have rational beliefs and cannot apply to more than one firm. Second, workers decide where to apply after examining the wage offers and the probability of getting hired. The higher wage and technology of the MNC forces the local firm to offer higher wage than before to avoid quality deterioration of its applicant pool. To formalize this thought, consider the first order conditions of the AEC minimization problem for the domestic firm and the MNC, respectively:

$$
\begin{aligned}
& \mathrm{T}\left[\mathrm{A}_{0}\right] \mathrm{C}^{\prime}\left[\mathrm{Q}\left[\mathrm{w}, \mathrm{H}, \pi, \mathrm{w}^{\mathrm{c}}\right]\right] \mathrm{Q}_{\mathrm{w}}\left[\mathrm{w}, \mathrm{H}, \pi, \mathrm{w}^{\mathrm{c}}\right]=-1, \\
& \mathrm{~T}\left[\mathrm{~A}_{1}\right] \mathrm{C}^{\mathrm{c}^{\prime}}\left[\mathrm{Q}\left[\mathrm{w}^{\mathrm{c}}, \mathrm{H}, \pi, \mathrm{w}\right]\right] \mathrm{Q}_{\mathrm{w}^{\mathrm{c}}}^{\mathrm{c}}\left[\mathrm{w}^{\mathrm{c}}, \mathrm{H}, \pi, \mathrm{w}\right]=-1,
\end{aligned}
$$

where superscript $\mathrm{c}$ denotes the $\mathrm{MNC}$, and $\mathrm{H}$ represents the domestic country's level of observable human capital that both firms utilize. Given the properties of the cost function, $\mathrm{T}\left[\mathrm{A}_{0}\right]<\mathrm{T}\left[\mathrm{A}_{1}\right]$ implies $\mathrm{w}^{\mathrm{c}}>\mathrm{w}$. Note that the greater the technology gap, the larger the differential in the wage offers. Equation ( $\left.7^{\prime}\right)$ is the reaction function of the local firm. It determines the wage it offers at each level of the MNC's wage, taking the latter as given. The same holds for equation (7"). The Nash equilibrium of the model is then given by the solution of the system of equations (7') and (7"):

$$
\begin{aligned}
& \mathrm{w}=\mathrm{w}\left[\mathrm{A}_{0}, \mathrm{H}, \pi, \mathrm{w}^{\mathrm{c}}\left[\mathrm{A}_{1}, \mathrm{H}, \pi, \mathrm{w}\right]\right], \\
& \mathrm{w}^{\mathrm{c}}=\mathrm{w}^{\mathrm{c}}\left[\mathrm{A}_{1}, \mathrm{H}, \pi, \mathrm{w}\left[\mathrm{A}_{0}, \mathrm{H}, \pi, \mathrm{w}^{\mathrm{c}}\right]\right],
\end{aligned}
$$

but from (7') and (7") we know that

$$
\left.\frac{\mathrm{dw}}{\mathrm{dw}^{\mathrm{c}}}\right|_{(21)}=-\frac{\mathrm{C}_{\mathrm{ww}^{\mathrm{c}}}}{\mathrm{C}_{\mathrm{ww}}}>0, \quad \text { and }\left.\frac{\mathrm{dw}^{C}}{\mathrm{dw}}\right|_{(21)}=-\frac{\mathrm{C}_{\mathrm{w}^{\mathrm{c}} \mathrm{w}}^{\mathrm{c}}}{\mathrm{C}_{\mathrm{w}^{\mathrm{c}} \mathrm{w}^{\mathrm{c}}}^{\mathrm{c}}}>0 .
$$


Hence the equilibrium can be easily characterized, since both reaction functions are upward sloping in the $w, w^{c}$ space, with each intercept being the wage a firm would offer if no competitor was in the market.

To ascertain if opening a subsidiary in the LDC is profitable, we must simply examine the first order condition of the MNC and examine if opening a plant in the LDC would provide positive profits. It is obvious from the profit condition that, depending on the DC's level of technology and the LDC's level of human capital, a production location in the LDC might not be profitable for a DC manufacturing firm. That is because the high training cost for the MNC would not be covered by the revenues. Hence, relocation becomes less and less likely the farther apart the levels of both human capital and technology are, because training costs increase as technology levels rise and/or observable human capital levels decline. This phenomenon explains not only why the lion share of FDI is among relatively similar countries (Markusen and Venables [1995]), but also the finding of Borensztein et. al. [1995] that the level of human capital is important to the success of FDI.

The LDC's firm now finds an additional impediment to production of the manufactured good. First, the price effect due to international trade raises its wage and depresses the quality of the applicant pool. Second, as the DC sets up a subsidiary and pays a higher efficiency wage, the DC skims off the high quality workers, which depresses the quality of the applicant pool for the LDC firm, yet again, as $\partial \mathrm{Q} / \partial \mathrm{w}^{\mathrm{c}}>0$. Both effects work to diminish the incentives for the LDC firm to produce and increase the likelihood that it will be driven out of business because it cannot generate positive profits.

\section{ENDOGENOUS TECHNOLOGICAL CHANGE UNDER ASYMMETRIC INFORMATION}

\subsection{Endogenous Technology}

We start by modifying the production function of the manufacturing firm to reduce the complexity of endogenous invention process. We assume that output is linear in technology, or

$$
Y_{t}=A_{t} F\left[L_{t}^{Y}\right]
$$

Once we allow for endogenous technological change, firms hire not only production workers, but also research workers, $\mathrm{R}_{\mathrm{t}}$, to produce new technology according to the standard 
technology production function

$$
\dot{\mathrm{A}}=\phi\left[\mathrm{R}_{\mathrm{t}}\right] \mathrm{A}_{\mathrm{t}},
$$

where $\phi[$.$] is assumed to satisfy the Inada conditions, with the exception of \phi^{\prime}[0]$, which is assumed to equal the constant $\gamma$. The slight modification of the Inada condition is necessary to insure stability of the system.

Since firms conduct research in and produce with firm-specific technology, firms must now train not only production but also research workers. In hiring for both types of positions, firms face an applicant pool with uncertain quality. Again, we will find that firms maximize profits by offering an efficiency wage to mitigate the informational asymmetry. The profit function of the firm can then be written as

$$
\rho_{t}=Y_{t}-\left(w_{t}+T\left[A_{t}\right] C\left[w_{t}\right]\right)\left(R_{t}+L_{t}^{Y}\right)
$$

where $\mathrm{C}\left[\mathrm{w}_{\mathrm{t}}\right]$ is a short for $\mathrm{C}\left[\mathrm{Q}\left[\mathrm{w}_{\mathrm{t}}, \mathrm{H}, \pi\right]\right]$, to simplify the notation until we discuss comparative statics.

The manufacturing sector in our economy now solves the following maximization problem:

$$
\begin{gathered}
\max _{\mathrm{L}_{\mathrm{t}}^{\mathrm{Y}}, \mathrm{R}_{\mathrm{t}}, \mathrm{w}_{\mathrm{t}}, \mathrm{A}_{\mathrm{t}}} \int_{0}^{\infty}\left(\mathrm{Y}_{\mathrm{t}}-\left(\mathrm{w}_{\mathrm{t}}+\mathrm{T}\left[\mathrm{A}_{\mathrm{t}}\right] \mathrm{C}\left[\mathrm{w}_{\mathrm{t}}\right]\right)\left(\mathrm{R}_{\mathrm{t}}+\mathrm{L}_{\mathrm{t}}^{\mathrm{Y}}\right)\right) \mathrm{e}^{-\delta \mathrm{t} d t} \\
\text { s.t. } \dot{\mathrm{A}}=\phi\left[\mathrm{R}_{\mathrm{t}}\right] \mathrm{A}_{\mathrm{t}},
\end{gathered}
$$

where $\delta$ represents the rate of time preference. Maximizing the Hamiltonian yields the following first order conditions:

$$
\begin{aligned}
& \mathrm{F}^{\prime}\left[\mathrm{L}^{\mathrm{Y}}\right]=\frac{\mathrm{w}+\mathrm{T}[\mathrm{A}] \mathrm{C}[\mathrm{w}]}{\mathrm{A}} \equiv \operatorname{AEC}[\mathrm{A}], \\
& \lambda \delta-\dot{\lambda}=\mathrm{F}\left[\mathrm{L}^{\mathrm{Y}}\right]+\lambda \phi[\mathrm{R}]-\left(\mathrm{L}^{\mathrm{Y}}+\mathrm{R}\right) \mathrm{T}^{\prime}[\mathrm{A}] \mathrm{C}[\mathrm{w}] . \\
& \mathrm{C}^{\prime}[\mathrm{w}]=-\frac{1}{\mathrm{~T}[\mathrm{~A}]}, \\
& \lambda \phi^{\prime}[\mathrm{R}]=\frac{\mathrm{w}+\mathrm{T}[\mathrm{A}] \mathrm{C}[\mathrm{w}]}{\mathrm{A}},
\end{aligned}
$$

We also add the transversality condition that 


$$
\lim _{t \rightarrow \infty} \lambda_{t} A_{t} e^{-\delta t}=0
$$

Equations (24) and (25) indicate that the productivity adjusted marginal products of research and production workers must equal their productivity adjusted cost (AEC). In the case of research workers, the AEC is weighted by the shadow value of technology, $\lambda$. Equation (26) is the familiar efficiency wage condition that determines the wage offered by manufacturing firms on the basis of training cost, independent of the labor supply.

Any long run equilibrium requires that the growth rate of research employment goes to zero (otherwise the AEC would reach infinity). This implies from equation (25) that the growth rate of the average efficiency cost must be zero in equilibrium. It follows immediately that the growth rate of the shadow value of technology, and the growth rate of labor in production must be zero, too. As research employment declines, and its productivity increases, the shadow value of technology declines. The only equilibrium value of $\lambda$ that satisfies equation (25) is then AEC/ $\gamma$. From equations (24) and (25) can the be utilized to establish a relationship between the rates of change of employment in the two sectors:

$$
\begin{aligned}
& \dot{\lambda} \phi^{\prime}[\mathrm{R}]+\lambda \phi^{\prime \prime}[\mathrm{R}] \dot{\mathrm{R}}=\frac{\mathrm{dAEC}}{\mathrm{dA}} \dot{\mathrm{A}}, \\
& \dot{\mathrm{L}}^{\mathrm{Y}}=\frac{\mathrm{dAEC} / \mathrm{dA}}{\mathrm{F}^{\prime \prime}[.]} \dot{\mathrm{A}},
\end{aligned}
$$

which allow us to summarize the steady state as $\dot{\lambda}=\dot{\mathrm{R}}=\dot{\mathrm{A}}=\dot{\mathrm{L}}^{\mathrm{Y}}=\mathrm{dAEC} / \mathrm{dA}=0$.

\subsection{Dynamics}

Substituting equations (24), (25) and (26) into (27) and the accumulation constraint, we can summarize the differential equations that determine the dynamics of the model,

$$
\begin{gathered}
\dot{\mathrm{A}}=\mathrm{A} \phi\left[\phi^{\prime(-1)}[\mathrm{AEC}[\mathrm{A}] / \lambda]\right] \\
\dot{\lambda}=\lambda \delta+\left(\phi^{\prime(-1)}[\mathrm{AEC}[\mathrm{A}] / \lambda]+\mathrm{F}^{\prime(-1)}[\mathrm{AEC}[\mathrm{A}]]\right) \mathrm{T}^{\prime}[\mathrm{A}] \mathrm{C}\left[\mathrm{C}^{\prime(-1)}[-1 / \mathrm{T}[\mathrm{A}]]\right] \\
-\mathrm{F}\left[\mathrm{F}^{(-1)}[\mathrm{AEC}[\mathrm{A}]]\right]-\lambda \phi\left[\phi^{\prime(-1)}[\mathrm{AEC}[\mathrm{A}] / \lambda]\right] .
\end{gathered}
$$

Equations (22') and (27') can be used to draw the phase diagram in the $\lambda$, A space. The slopes of the $\dot{\lambda}=0$ and $\dot{A}=0$ lines around the equilibrium can readily be obtained from (22') and (27') 


$$
\begin{gathered}
\left.\frac{\mathrm{d} \lambda}{\mathrm{dA}}\right|_{\dot{A}=0}=\frac{\mathrm{dAEC}}{\mathrm{dA}} \frac{1}{\gamma}, \\
\left.\frac{\mathrm{d} \lambda}{\mathrm{dA}}\right|_{\lambda=0}=-\frac{\mathrm{L}^{\mathrm{Y}}\left(\frac{\left(\mathrm{T}^{\prime}[\mathrm{A}] \mathrm{C}^{\prime}[.]\right)^{2}}{\mathrm{~T}[\mathrm{~A}] \mathrm{C}^{\prime \prime}[.]}+\mathrm{C}[.] \mathrm{T}^{\prime \prime}[\mathrm{A}]\right)}{\delta}<0 .
\end{gathered}
$$

Equation (31) represents the convex $\dot{A}=0$ line that slopes downward before its minimum, and intercepts the line $\dot{\lambda}=0$ at $\lambda=\mathrm{AEC}\left[\mathrm{A}^{*}\right] / \gamma$. Further research would increase training costs in excess of the marginal benefit to the firm. Note also, that firms cannot be forced to adopt a technology that provides negative profits, and that it can "jump" to use older technology even if several generation of newer technologies are available. The $\dot{\lambda}=0$ line is given in equation (32), and is downward sloping due to the convexity of the AEC in A, e.g. $\mathrm{d}\left(\mathrm{T}^{\prime}[\mathrm{A}] \mathrm{c}[\mathrm{w}]\right) / \mathrm{dA}>0$.

The phase trajectories that map out the dynamic moments of the system indicate in Figure 4 that any loci off the saddle path violate the transversality condition. For any $\dot{\lambda}=0$ technology is increasing, and for any A to the west of the $\dot{\lambda}=0$ demarcation line $\dot{\lambda}=0$, so that the shadow value of technology declines as technology accumulates. The equilibrium is a saddle point with a downward sloping stable and an upward sloping unstable branch.

The analysis of the local phase diagram can be confirmed by a complete local stability analysis. The linearization around the steady state yields

$$
\left[\begin{array}{c}
\dot{\mathrm{A}} \\
\dot{\lambda}
\end{array}\right]=\left[\begin{array}{cc}
0 & -\frac{\mathrm{A} \gamma^{2}}{\lambda \phi^{\prime \prime}[0]} \\
\mathrm{L}^{\mathrm{Y}}\left(-\frac{\left(\mathrm{C}^{\prime}[\mathrm{w}] \mathrm{T}^{\prime}[\mathrm{A}]\right)^{2}}{\mathrm{~T}[\mathrm{~A}] \mathrm{C}^{\prime \prime}[\mathrm{w}]}+\mathrm{T}^{\prime \prime}[\mathrm{A}] \mathrm{C}[\mathrm{w}]\right. & \delta
\end{array}\right]\left[\begin{array}{c}
\mathrm{A}-\mathrm{A}^{*} \\
\lambda-\lambda^{*}
\end{array}\right]
$$

The Jacobian reveals immediately that the determinant is negative for reasonably small values of the rate of time preference, which confirms our analysis of the phase diagram that the equilibrium is locally saddle point stable.

\subsection{Dynamic adjustment to a World Price Shock.}

Above we have briefly discussed the possibility of receiving a technology spillover, and under what circumstances a country would be willing to adopt such a windfall. As seen above, the economy will not adopt a new technology beyond $\mathrm{A}^{*}$ because training costs, just for 
production workers, would exceed the revenues from sales of Y, given their level of ability and human capital at a given world price. A change in the world price changes the incentives to produce technology permanently.

Our representative example will be a decline in the relative price of the agricultural good. In that case the small open economy finds it relatively more profitable to expand its manufacturing production and its technology production. Here it is helpful to recall the intuition we built in the static model. There it was shown that a decline in the relative price of manufacturing provides a higher quality of workers at the same efficiency wage. For any given level of technology, training costs shift down and profits in manufacturing rise again due to the fall in $\pi$.

The new equilibrium is characterized by a lower AEC, which must be due to a higher level of technology. Hence the $\dot{\lambda}=0$ line can be shown to shift East. The transition is described in Figure 5. At the old level of technology, the shadow value of another unit of technology is now positive. The economy jumps onto the new transition path, $\mathrm{E}_{1}$, hires workers into the $\mathrm{R} \& \mathrm{D}$ sector and sees the shadow value decline as it moves to the new equilibrium $A_{1}^{*}$ at $\mathrm{E}_{2}$.

Finally a word on the dynamic effect of firm location. As discussed in the formal location analysis, the entry of a higher wage and technology multinational forces the domestic firm to offer a higher wage. From our dynamic analysis we know that this can be achieved only in two ways. First, if the country has not yet met its steady state, it will reduce its rate of technology accumulation and arrive at a lower steady state, one characterized by a higher AEC. If, on the other hand, the country has already reached its steady state, it will not only have to raise its wage, but also lower the technology employed because it faces a reduction in the quality of the applicant pool. Here the analysis is analogous to the effects on the local firm if the relative price of the manufacturing good declines. Hence under asymmetric information the multinational results in a dumbing down of the production process in the domestic firm, and an increase in the average wage paid in manufacturing, which leaves the country better off in utility terms but certainly not in terms of its level of GDP.

\section{SUMMARY AND CONCLUDING REMARKS}

This paper explores the human dimension to FDI: informational asymmetries as MNCs must train workers to work with firm specific technology. Figure 3 summarizes the important 
conclusions of this paper. First, it exhibits the informational gains from trade, as the country with the comparative advantage in training enjoys a higher quality applicant pool and lower efficiency wages. Second we find that the farther the cost curves are apart, the less likely FDI will be. As the cost curves indicate both the difference in the levels of technologies and human capital between the countries, we know that similar countries are more likely to receive FDI. Countries that do not provide a minimum level of human capital cannot attract technologically superior FDI, because MNCs find that the average cost of training is too high.

Most importantly efficiency wages can explain why FDI does not raise the wage level as a whole for the country, but only for workers employed in the MNC. Informational asymmetries force firms to pay wages that control the quality of the applicant pool, rather than clear the labor market in manufacturing. This paper also shows that the MNC pays a higher wage than the domestic firm, because the MNC introduces a superior technology, and incurs higher training costs. This provides incentives to raise the wage in order to increase the quality of its applicant pool. Despite working with the same technology, workers in the LDC receive a lower wage, than in the MNC's home country, because the MNC faces lower information costs and higher quality workers in the home country. This generates multiple wage equilibria.

We find in the dynamic analysis that the model is entirely void of scale effects. That is, growth ceases in this model, even if ever more sophisticated technology were available, because the cost of adoption would eventually outpace revenues. To introduce a full fledged general equilibrium adverse selection model, we had to make some important simplifications. If both technology and human capital would be endogenous, sustained growth would clearly be possible. However, we are certain that it would not overturn the qualitative nature of our location results. We have seen above that international trade mitigates the effect of informational asymmetries. Hence it is not surprising to find that there is a long history in the literature on informational asymmetries that explores the room for policy to achieve welfare improvements. Weiss [1990] and especially Copeland [1989], and Bulow and Summers [1989] address the wealth of welfare issues inherent in models of informational asymmetries. A full fledged commercial policy analysis is left for future research. 


\section{REFERENCES}

Aitken, Brian, Ann Harrison, and Robert E. Lipsey. 1995. "Wages and Foreign Ownership: A Comparative Study of Mexico, Venezuela, and the United States." NBER Working Paper No. 5102

Becker, Gary. 1975. Human Capital. Chicago:University of Chicago Press.

Borensztein, Eduardo, Jose De Gregorio, and Jong-Wha Lee. (1995). "How Does Foreign Direct Investment Affect Economic Growth?" NBER Working Paper No. 5057.

Brecher, Richard A. 1992. "An Efficiency-Wage Model With Explicit Monitoring and Welfare in an Open Economy." Journal of International Economics 32(1-2): 179-91

Brecher, Richard A., and Ehsan U. Choudhri. 1994. "Pareto Gains From Trade, Reconsidered: Compensating for Jobs Lost." Journal of International Economics 36(3-4), 223-38.

Bulow, Jeremy I., and Lawrence H. Summers. 1986. "A Theory of Dual labor Markets With Applications to Industrial Policy, Discrimination and Keynesian Unemployment." Journal of Labor Economics 4: 376-414.

Copeland, Brian R. 1989. "Efficiency Wages in a Ricardian model of international trade." Journal of International Economics 27: 221-244.

Davis, Stephen J. 1992. "Cross Country Patterns of Change in Relative Wages." In O. Blanchard and S. Fisher, eds., NBER Macroeconomic Annual.

Dixit, Avinash. 1989. "Trade and Insurance with Adverse Selection." Review of EconomicStudies 56: 235-248.

Dixit, Avinash. 1994. "Risk-sharing, Adjustment, and Trade." Journal of International Economics 36: 263-285.

Dunning, John H. 1977. "Trade Location of Economic Activity and MNE: A Search for an Electic Approach." In Ohlin, B., P.O. Hesselborn, and P.M. Wijkman, eds., The International Allocation of Economic Activity. London, Macmillan: 395-418.

Dunning, John, H. 1981. International Production and the Multinational Enterprise. London: George Allen and Unwin.

Easterly, William, Michael Kremer, Lant Pritchett, and Lawrence H. Summers. (1993). "Good Policy of Good Luck? Country Growth Performance and Temporary Shocks." Journal of 
Monetary Economics 32: 459-483.

Eicher Theo S. 1995. "Trade Development and Converging Growth Rates: Dynamic Gains From Trade Reconsidered." University of Washington Working Paper.

Eicher, Theo S. 1996. "Endogenous Human Capital and Technological Change." Review of Economic Studies 63: 127-145.

Eicher Theo S. and Stephen J. Turnovsky. (1996). "Toward a General Model of Economic Growth." University of Washington Working Paper.

Ethier, Wilfred J. 1986. "The Multinational Firm." Quarterly Journal of Economics101: 805833.

Feenstra, Robert C. and Gordon H. Hanson. 1995. "Foreign Direct Investment and Relative Wages." NBER Working Paper No. 5122.

Foster, Andrew, and Mark Rosenzweig. 1993. "Information Flows and Distribution in Labor Markets in Rural Areas in Developing Countries." Proceedings of the World Bank Annual Conference on Development Economics 1992: 173-203.

Hummels, David L., and Robert M. Stern. 1994. "Evolving Patterns of North American Merchandise Trade and Foreign Direct Investment, 1960-1990." The World Economy 17: $5-29$.

Jones, Charles. 1995. "Time Series Tests of Endogenous Growth Models." Quarterly Journal of Economics 110: 495-527.

Kalaitzidakis, Pantelis G. 1996. "On-The-Job Training Under Firm Specific Innovation and Worker Heterogeneity." Working Paper No. 96-2, University of Cyprus.

Krueger, Alan B. 1988. "The Determinants of Queues for Federal Jobs." Industrial and Labor Relations Review 41: 567-581.

Mankiw, N. Gregory, David Romer, and David N. Weil. (1992). "A Contribution to the Empirics of Economic Growth." Quarterly Journal of Economics 107: 407-437.

Markusen James R. 1995. "The Boundaries of Multinational Enterprises and the Theory of International Trade." Journal of Economic Perspectives 9: 169-189.

Markusen, James R., and Anthony J Venables. 1995. "Multinational Firms and the New Trade Theory." NBER Working Paper No. 5036. 
Nalebuff, Barry, and Joseph Stiglitz. 1982. "Prices and Quality." Princeton University Econometric Research Program Paper No. 297.

Phelps, Edmund. 1994. Structural Slumps. Cambridge MA: Harvard University Press.

Weiss, Andrew. 1980. "Job Queues and Layoff in Labor Markets with Flexible Wages." Journal of Political Economy 88: 526-538.

Weiss, Andrew. 1990. Efficiency Wages: Models of Unemployment, Layoffs, and Wage Dispersion. Princeton University Press.

Young, Alwyn. 1993. "Invention and Bounded Learning By Doing." Journal of Political Economy 101(3),: 443-72 